\title{
On Thermodynamic Possibility of Retort Steel Components Interaction with Titanium Chlorides and Oxygen During Kroll Process
}

\author{
IVAN CHERVONYJ ${ }^{1}$, DMYTRO LISTOPAD ${ }^{1}$, ANGELINA GAB ${ }^{2}$, VICTOR MALYSHEV², ELENA IO NELA NEACSU ${ }^{3}$, \\ CRISTINA DONATH ${ }^{3 *}$, VIRGIL COSNTANTIN, ANA-MARIA POPESCU ${ }^{3 *}$ \\ 1Department of Metallurgy of Non-Ferrous Metals, Zaporizhzhia State Engineering Academy, Soborny Ave., 226, Zaporizhzhia \\ Ukraine \\ ${ }^{2}$ Institute for Engineering Technologies, Open International University of Human Development Ukraine, 23 Lvivska Str., Kyiv \\ 03115, Ukraine \\ ${ }^{3}$ llie Murgulescu Institute of Physical Chemistry of the Romanian Academy, Laboratory of Electrochemistry and Corrosion, \\ 202 Splaiul Independentei, 060021, Bucharest, Romania
}

\begin{abstract}
Thermodynamic analysis was carried out of the possible effects of interaction reactions of the main components of the metallic retort $(\mathrm{Fe}, \mathrm{Ni}, \mathrm{Cr}, \mathrm{Mn}$ ) with titanium chlorides and with oxygen, during magnesium thermal method of titanium obtaining. The temperature dependences of $D G$ for the conversion of metals into their chlorides and oxides allowed to establishe the temperature ranges in which the above reactions take place.
\end{abstract}

Keywords: titanium sponge, titanium chlorides, chemical reaction of the elements ( $\mathrm{Fe}, \mathrm{Cr}, \mathrm{Ni}, \mathrm{Mn}$ ) with titanium chlorides and oxygen, Gibbs free energy of reactions

Titanium is the most common metal and has a unique combination of properties and so it has generated a lot of research studies [1-6]. Due to the high specific strength, refractoriness and heat resistance, it is widely used in the aerospace industry, shipbuilding industry and nuclear industry. However, the complex composition of the titanium-containing minerals and a high affinity of titanium to oxygen create difficulties in obtaining pure titanium, necessitating a plurality of process stages, and complex hardware and flow chart implemented in the industrial production of titanium with magnesium as reduction agent (Kroll process). Broad effective use of titanium is limited by its high production cost. Numerous attempts of industrial implementation of alternative ways of manufacturing of titanium were unsuccessful.

Chlorination of enriched titanium ore (ilmenite, rutile) yielding titanium tetrachloride and its subsequent thermal reduction to metallic titanium by magnesium is the basic modern industrial method of titanium production. Stainless steel retorts (reactors) are used in this production. When interacting with titanium sponge, both iron and nickel components in steels form liquid eutectics at high temperatures. The sponge titanium is polluted (contaminated) and the walls of the retort become flimsy and can be degraded. Therefore, the heating of the retortis limited to $1173 \mathrm{~K}$. The titanium sponge, in contacts with the steel walls of the equipment is contaminated by the material of the walls; that is why it undergoes purification or is used as a low-grade material. After multistage processing of metallic titanium, only $10-15 \%$ of pure titanium is produced from this titanium raw material. During the Kroll process [7]. the reduction of titanium tetrachloride with magnesium is accompanied by a significant heat release, as well as continuous change in the surface area. The maximum temperature is limited by steel gear resistance, because above $1273 \mathrm{~K}$ the contact of titanium with the material of the reactor could lead to the formation of eutectics alloys and burning out wall of the reactor, as well as the transition of iron and nickel in the sponge layers adjacent to wall to a depth of about 20-
$40 \mathrm{~mm}$. This process leads to titanium sponge contamination [8-13]. During reduction process there is a need to maintain reactor wall temperature within 1093$1123 \mathrm{~K}$. For this purpose there are used nichrome heaters and air coolers placed in a furnace where reactor is located. The quality of titanium sponge is determined by the content of impurities in it. The lower content of impurities the higher the quality of titanium sponge. Sources of impurities are: raw materials ( $\mathrm{Mg}$ and $\mathrm{TiCl}_{\mathrm{A}^{\prime}}$, argon), equipment (material of the reactor) and the environment (air leaks in vacuum separator).[14] About 70 chemical reactions are possible in the system $\mathrm{TiCl}_{4}(\mathrm{Ti}(\mathrm{IV}))-\mathrm{TiCl}_{3}-\mathrm{TiCl}_{2}(\mathrm{Ti}(\mathrm{II})-\mathrm{TiCl}-\mathrm{Ti}-\mathrm{Mg}$ $\mathrm{MgCl}-\mathrm{MgCl}_{2}(\mathrm{Mg}(\mathrm{III}))^{4}$ which were selected from the point of view of thermodynamics and kinetics [6]. A complex multiphase contribution of the components of the steel retort to the overall reactions may takes place.

The objective of this work is the thermodynamic study of the interaction of metals ( $\mathrm{Fe}, \mathrm{Cr}, \mathrm{Ni}, \mathrm{Mn}$ ) with titanium chlorides and oxygen, with application of a thermodynamic analysis method in order to show possible sources of impurities in a titanium sponge from retort material.

\section{Methodology of work}

For theoretical studying of behavior of the basic components of a steel ( $\mathrm{Fe}, \mathrm{Cr}, \mathrm{Ni}, \mathrm{Mn}$ ) in the environment of oxygen and titanium chlorides theoretical calculations of thermodynamic probability of interaction processes have been made. And, for the first approach there was assumed, that alloying elements represent pure metals, instead of alloys formed with each other. Also, formation of protective oxides film on a surface of metal that prevent process of oxidation of metal was not considered in calculations. Kinetic and catalytic components of carried out processes were not considered in calculations.

For graphical representation of paths of possible processes some schemes have been made - in which initial metals and oxides interactions with titanium chlorides and oxygen are represented. Reagents and/or products of reaction are shown with factors considered in calculations. In these schemes the possibility of formation 
of the lowest oxides and metal chlorides and their interaction with the lowest titanium chlorides are noted.

According to the rules adopted in metallurgical thermodynamics [15], calculations were carried out at 1 mol-atom of metal and, if the reaction has formed a compound with a multiple number of atoms $\left(\mathrm{Fe}_{3} \mathrm{O}_{4}, \mathrm{Cr}_{2} \mathrm{O}_{3}\right.$, $\mathrm{NiO}, \mathrm{Mn}_{2} \mathrm{O}_{3}$ etc.), then the stoichiometric coefficients were divided by this divisible number to obtain the equation with fractional coefficients. Since the quantity of the assumed reactions for some elements is great, as a matter of convenience, for each element there were some graphs of Gibbs energy change DG from temperature constructed no more than nine reactions are presented on each graph.

Values of $\Delta \mathrm{G}$ were calculated using the equation $\Delta \mathrm{G}=$ $\Delta \mathrm{H}-\mathrm{T} \times \Delta \mathrm{S}$. Calculations were made for each temperature range (on the graphs, straight lines between bends in which at least one of the components changes its structure and, accordingly, thermodynamic properties). Within such segments, calculations of the heat capacity changes for the components of the reaction equation were made according to the equations of the type $\Delta C p=\Delta A+\Delta B * T+$ $+\Delta C * T^{-2}$, where each coefficient $(A, B, C)$ of the equation is calculated in accordance with the coefficients in the chemical equation for which the calculation was performed. The data for such calculations were taken for all substances from tables of one source $[1,15]$.

\section{Results and discussions}

For the theoretical study of the behavior of the main components of steel ( $\mathrm{Fe}, \mathrm{Cr}, \mathrm{Ni}, \mathrm{Mn})$ under the interaction with oxygen and titanium chlorides there were calculated thermodynamic probability processes of interaction of alloying elements with chlorides of titanium and oxygen. If the Gibbs free energy change for a reaction is negative, that process may take place. Graphical representation of $\Delta G$ vs. T for the possible ways of proceeding of processes is performed on the basis of different reactions.

A combination of reactions shows the possibility of formation of lower oxides and chlorides of the metal alloy and their interaction with the lower chlorides of titanium, $\mathrm{TiCl}_{3}$ and $\mathrm{TiCl}_{2}$.

Let us consider the behaviour of the main components of the reactor wall material.

Iron: Possible reactions of formation of iron chlorides under the influence of titanium chlorides are presented in the following reactions by forming:

a) $\mathrm{FeCl}$

$$
\begin{aligned}
& \mathrm{Fe}+2 \mathrm{TiCl}_{4} \rightarrow \mathrm{FeCl}_{2}+2 \mathrm{TiCl}_{3} \\
& \mathrm{Fe}+\mathrm{TiCl}_{4} \rightarrow \mathrm{FeCl}_{2}+\mathrm{TiCl}_{2} \\
& \mathrm{Fe}+2 \mathrm{TiCl}_{3} \rightarrow \mathrm{FeCl}_{2}+2 \mathrm{TiCl}_{2}
\end{aligned}
$$$$
\text { b) } \mathrm{FeCl}_{3}
$$

$$
\begin{aligned}
& \mathrm{FeCl}_{2}+\mathrm{TiCl}_{4} \rightarrow \mathrm{FeCl}_{3}+\mathrm{TiCl}_{3} \\
& \mathrm{FeCl}_{2}+\mathrm{TiCl}_{3} \rightarrow \mathrm{FeCl}_{3}+\mathrm{TiCl}_{2} \\
& \mathrm{Fe}+3 \mathrm{TiCl} \rightarrow \mathrm{FeCl}_{3}+3 \mathrm{TiCl}_{3} \\
& \mathrm{Fe}+3 \mathrm{TiCl}_{3} \rightarrow \mathrm{FeCl}_{3}+3 \mathrm{TiCl}_{2} \\
& \mathrm{Fe}+2 \mathrm{TiCl}_{4} \rightarrow \mathrm{FeCl}_{3}+\mathrm{TiCl}_{3}+\mathrm{TiCl}_{2}
\end{aligned}
$$

The dependence of $\Delta G_{\text {f }}$ for reaction (3) was not built on Figure 1 since the calculated values (from 300 to $520 \mathrm{~kJ}$ / mole) indicate that at any of the considered temperatures the process is not possible thermodynamically because all DG values are positive.

From the presented graphs on figure 1 it is possible to state that interaction of iron with titanium chlorides can proceed only on some of the considered ways. Reaction (1) proceeds at low temperatures (up to $800 \mathrm{~K}$ ) and at temperatures above $1200 \mathrm{~K}$. Reactions (2) and (6) can proceed at low temperatures (to $600 \mathrm{~K}$ and $500 \mathrm{~K}$ ) accordingly. Above this temperature passing of reactions thermodynamically is not possible. From figure 1 it can see that formation of oxides of iron from metal and their further oxidation to the highest oxidation states is thermodynamically possible atall considered temperature range.
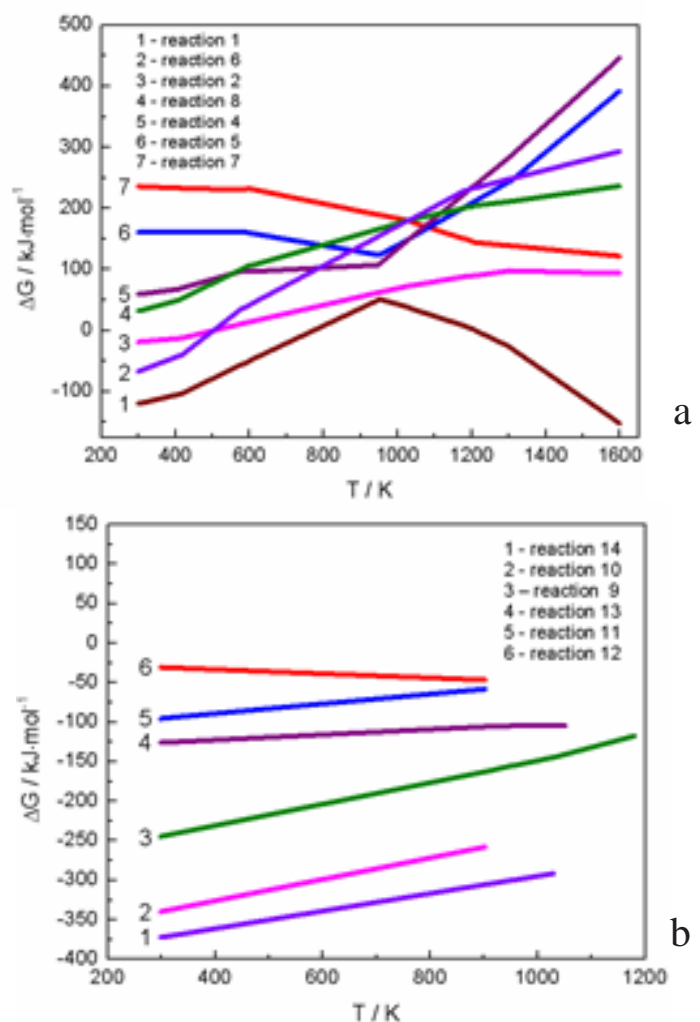

Fig. 1. Temperature dependences of $\Delta G_{T}$ for the possible ways of metallic iron and its oxide compounds at interaction with titanium chlorides (a) and oxygen (b)

At normal conditions the formation of three iron oxides takes place according to the following reactions:

$$
\begin{aligned}
& \mathrm{Fe}+1 / 2 \mathrm{O}_{2} \rightarrow \mathrm{FeO} \\
& \mathrm{Fe}+2 / 3 \mathrm{O}_{2} 1 / 3 \rightarrow \mathrm{Fe}_{3} \mathrm{O}_{4} \\
& \mathrm{FeO}+1 / 6 \mathrm{O}_{2} 1 / 3 \rightarrow \mathrm{Fe}_{3} \mathrm{O}_{4} \\
& \mathrm{Fe} \mathrm{O}_{4}+1 / 4 \mathrm{O}_{2} 3 / 2 \rightarrow \mathrm{Fe}_{2} \mathrm{O}_{3} \\
& \mathrm{FeO}+1 / 4 \mathrm{O}_{2} 1 / 2 \rightarrow \mathrm{Fe}_{2} \mathrm{O}_{3} \\
& \mathrm{Fe}+3 / 4 \mathrm{O}_{2} 1 / 2 \rightarrow \mathrm{Fe}_{2} \mathrm{O}_{3}
\end{aligned}
$$

Chromium: The probably formation of three chromium chlorides under the influence of titanium chlorides is presented in the following reactions, by forming:

a) $\mathrm{CrCl}_{2}$

b) $\mathrm{CrCl}_{3}$

$$
\begin{aligned}
& \mathrm{Cr}+2 \mathrm{TiCl}_{4} \rightarrow \mathrm{CrCl}_{2}+2 \mathrm{TiCl}_{3} \\
& \mathrm{Cr}+\mathrm{TiCl}_{4} \rightarrow \mathrm{CrCl}_{2}+\mathrm{TiCl}_{2} \\
& \mathrm{Cr}+2 \mathrm{TiCl}_{3} \rightarrow \mathrm{CrCl}_{2}+2 \mathrm{TiCl}_{2}
\end{aligned}
$$

c) $\mathrm{CrCl}_{4}$

$$
\begin{aligned}
& \mathrm{Cr}+3 \mathrm{TiCl}_{4} \rightarrow \mathrm{CrCl}_{3}+3 \mathrm{TiCl}_{3} \\
& \mathrm{Cr}+3 \mathrm{TiCl}_{3} \rightarrow \mathrm{CrCl}_{3}+3 \mathrm{TiCl}_{2} \\
& \mathrm{Cr}+2 \mathrm{TiCl}_{4} \rightarrow \mathrm{CrCl}_{3}+\mathrm{TiCl}_{2}+\mathrm{TiCl}_{3} \\
& \mathrm{CrCl}_{2}+\mathrm{TiCl}_{4} \rightarrow \mathrm{CrCl}_{3}+\mathrm{TiCl}_{3} \\
& \mathrm{CrCl}_{2}+\mathrm{TiCl}_{3} \rightarrow \mathrm{CrCl}_{3}+\mathrm{TiCl}_{2}
\end{aligned}
$$

$$
\begin{aligned}
& \mathrm{Cr}+4 \mathrm{TiCl}_{4} \rightarrow \mathrm{CrCl}_{4}+4 \mathrm{TiCl}_{3} \\
& \mathrm{Cr}+3 \mathrm{TiCl}_{4} \rightarrow \mathrm{CrCl}_{4}+2 \mathrm{TiCl}_{3}+\mathrm{TiCl}_{2} \\
& \mathrm{Cr}+4 \mathrm{TiCl}_{3} \rightarrow \mathrm{CrCl}_{4}+4 \mathrm{TiCl}_{2} \\
& \mathrm{Cr}+2 \mathrm{TiCl}_{4} \rightarrow \mathrm{CrCl}_{4}+2 \mathrm{TiCl}_{2} \\
& \mathrm{CrCl}_{3}+\mathrm{TiCl}_{4} \rightarrow \mathrm{CrCl}_{4}+\mathrm{TiCl}_{3} \\
& \mathrm{CrCl}_{3}+\mathrm{TiCl}_{3} \rightarrow \mathrm{CrCl}_{4}+\mathrm{TiCl}_{2}
\end{aligned}
$$


From figure 2 it can be seen that chromium and its chlorides can interact with titanium chlorides at low temperatures (nearby $1000 \mathrm{~K}$ ); at more heat interaction is thermodynamically not probable.

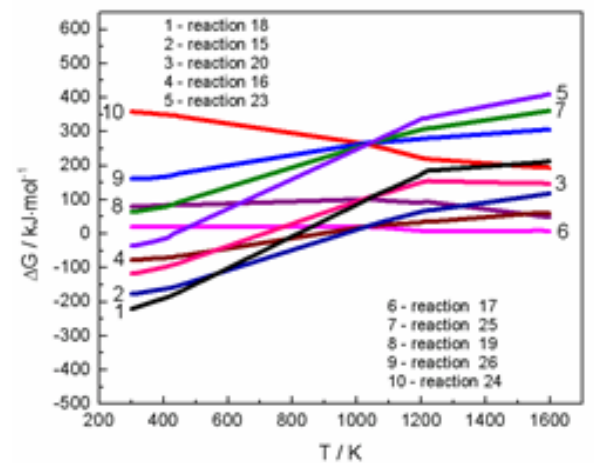

a

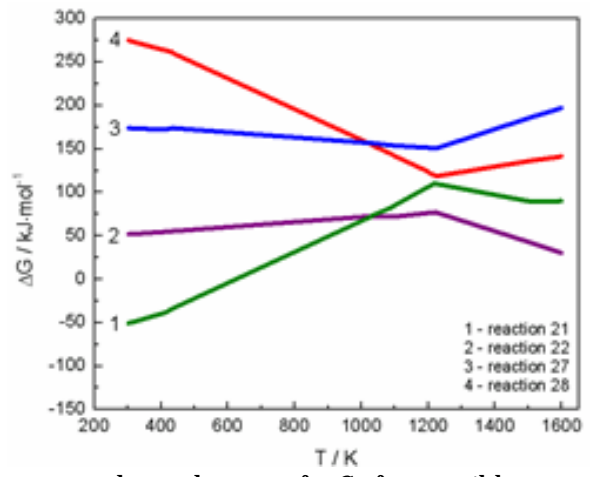

b

Fig. 2. Temperature dependences of $\Delta G_{T}$ for possible ways of metal chrome and its chlorides oxidation at interaction with titanium chlorides

There are three stable chromium oxides $\left(\mathrm{Cr}_{2} \mathrm{O}_{3}, \mathrm{CrO}_{2}\right.$ and $\mathrm{CrO}_{3}$ ) and the possible reaction of these substances under the influence of atmospheric oxygen on the wall of the reactor are presented in the following reactions:

$$
\begin{aligned}
& \mathrm{Cr}+3 / 4 \mathrm{O}_{2} \rightarrow 1 / 2 \mathrm{Cr}_{2} \mathrm{O}_{3} \\
& \mathrm{Cr}+\mathrm{O}_{2} \rightarrow \mathrm{CrO}_{2} \\
& \mathrm{Cr}_{2} \mathrm{O}_{3}+1 / 2 \mathrm{O}_{2} \rightarrow 2 \mathrm{CrO}_{2} \\
& \mathrm{CrO}_{2}+1 / 2 \mathrm{O}_{2} \rightarrow \mathrm{CrO}_{3} \\
& \mathrm{Cr}_{2}+3 / 2 \mathrm{O}_{2} \rightarrow 2 \mathrm{CrO}_{3} \\
& \mathrm{Cr}+3 / 2 \mathrm{O}_{2} \rightarrow \mathrm{CrO}_{3}
\end{aligned}
$$

Figure 3 presents the formation of all three oxides of chrome which are thermodynamically possible, however, in practice chrome oxidation can be complicated by a dense oxide layer on a surface of chromium metal which prevents formation of other oxides. Oxidising reactions of the lowest oxides to higher oxidation states is thermodynamically unprofitable process.

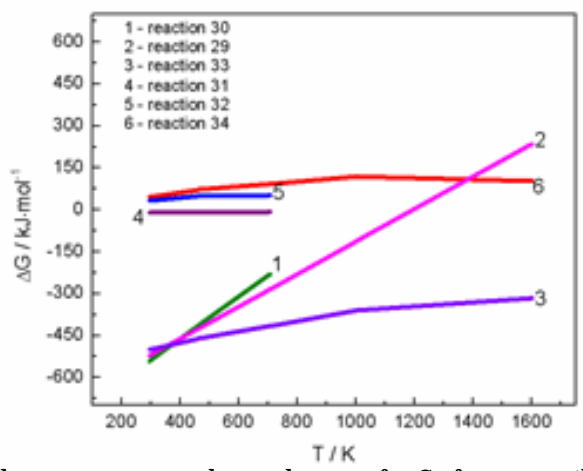

Fig. 3. The temperature dependence of $\Delta G_{T}$ for a possible way of metallic chrome and its oxides oxidation under the influence of oxygen

Nickel: Possible reactions for formation of nickel dichloride and nickel oxide are the followings:

$$
\begin{aligned}
& \mathrm{Ni}+2 \mathrm{TiCl}_{4} \rightarrow \mathrm{NiCl}_{2}+2 \mathrm{TiCl}_{3} \\
& \mathrm{Ni}+\mathrm{TiCl}_{4} \rightarrow \mathrm{NiCl}_{2}+\mathrm{TiCl}_{2} \\
& \mathrm{Ni}+2 \mathrm{TiCl}_{3} \rightarrow \mathrm{NiCl}_{2}+2 \mathrm{TiCl}_{2} \\
& \mathrm{Ni}+1 / 2 \mathrm{O}_{2} \rightarrow \mathrm{NiO}
\end{aligned}
$$

As it appears from graphs presented in figure 4, interaction of titanium chlorides with nickel is thermodynamically possible at low temperatures ( to 600 $\mathrm{K}$ ) according to reaction (35). At higher temperatures the interaction of nickel with titanium chlorides is thermodynamically not possible. On the basis of work [16] it is possible to assume that most part of nickel getting to titanium sponge from a reactor material passes through a formation stage of $\mathrm{MgNi}_{2}$ intermetallic compound.

From figure 4 it is visible, that oxide formation is thermodynamically possible at all considered temperature range. However, nickel, as well as chromium, forms the dense oxide layer which protects metal from the further oxidation.

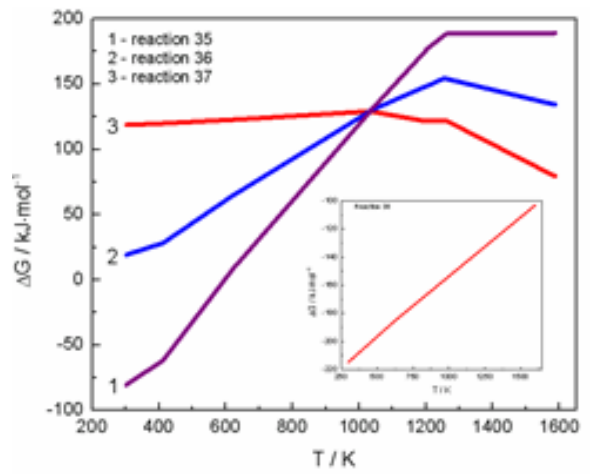

Fig. 4. Temperature dependences of $\Delta G_{T}$ for the possible ways of interaction of metal nickel with titanium chlorides and oxygen (figure inset)

Manganese: Possible paths for formation of manganese chlorides under the influence of titanium chlorides are presented by the following reactions with formation of:
a) $\mathrm{MnCl}_{2}$
$\mathrm{Mn}+2 \mathrm{TiCl}_{4} \rightarrow \mathrm{MnCl}_{2}+2 \mathrm{TiCl}_{3}$
$\mathrm{Mn}+\mathrm{TiCl}_{4} \rightarrow \mathrm{MnCl}_{2}+\mathrm{TiCl}_{2}$
$\mathrm{Mn}+2 \mathrm{TiCl}_{3} \rightarrow \mathrm{MnCl}_{2}+2 \mathrm{TiCl}_{2}$
b) $\mathrm{MnCl}_{3}$

$$
\begin{aligned}
& \mathrm{Mn}+3 \mathrm{TiCl}_{4} \rightarrow \mathrm{MnCl}_{3}+3 \mathrm{TiCl}_{3} \\
& \mathrm{Mn}+3 \mathrm{TiCl}_{3} \rightarrow \mathrm{MnCl}_{3}+3 \mathrm{TiCl}_{2} \\
& \mathrm{Mn}+2 \mathrm{TiCl}_{4} \rightarrow \mathrm{MnCl}_{3}+\mathrm{TiCl}_{3}+\mathrm{TiCl}_{2} \\
& \mathrm{MnCl}_{2}+\mathrm{TiCl}_{4} \rightarrow \mathrm{MnCl}_{3}+\mathrm{TiCl}_{3}
\end{aligned}
$$$$
\mathrm{MnCl}_{2}+\mathrm{TiCl}_{3} \rightarrow \mathrm{MnCl}_{3}+\mathrm{TiCl}_{2}
$$
c) $\mathrm{MnCl}_{\mathrm{A}}$$$
\mathrm{Mn}+4 \mathrm{TiCl}_{4} \rightarrow \mathrm{MnCl}_{4}+4 \mathrm{TiCl}_{3}
$$$$
\mathrm{Mn}+3 \mathrm{TiCl}_{4} \rightarrow \mathrm{MnCl}_{4}+2 \mathrm{TiCl}_{3}+\mathrm{TiCl}_{2}
$$$$
\mathrm{Mn}+4 \mathrm{TiCl}_{3} \rightarrow \mathrm{MnCl}_{4}+4 \mathrm{TiCl}_{2}
$$$$
\mathrm{Mn}+2 \mathrm{TiCl}_{4} \rightarrow \mathrm{MnCl}_{4}+2 \mathrm{TiCl}_{2}
$$$$
\mathrm{MnCl}_{3}+\mathrm{TiCl}_{4} \rightarrow \mathrm{MnCl}_{4}+\mathrm{TiCl}_{3}
$$$$
\mathrm{MnCl}_{3}+\mathrm{TiCl}_{3} \rightarrow \mathrm{MnCl}_{4}+\mathrm{TiCl}_{2}^{3}
$$

The dependence for $\Delta \mathrm{G}_{\mathrm{T}}$ of reaction (47) was not built since the received values (from 720 to $1520 \mathrm{~kJ} / \mathrm{mole}$ ) indicate that at any of the considered temperatures process passing is not thermodynamically possible.

On figure 5 it is visible that reactions (39-41) passing between $\mathrm{TiCl}_{4}, \mathrm{TiCl}_{3}$ and manganese with formation $\mathrm{MnCl}_{2}$ are thermodynamically probable. The further oxidation of $\mathrm{MnCl}_{2}$ is thermo-dynamically impossible. How ever, the flow of impurities in the magnesium block of spongy titanium does not occur in the low (less than $1 \%$ ) content of manganese in steel used for the manufacture of reactor.

Interactions of manganese and its oxides ( $\mathrm{MnO}, \mathrm{Mn}_{3} \mathrm{O}_{4}$, $\mathrm{Mn}_{2} \mathrm{O}_{3}$ ) with oxygen are described by the following reactions: 


$$
\begin{aligned}
& \mathrm{Mn}+1 / 2 \mathrm{O}_{2} \rightarrow \mathrm{MnO} \\
& \mathrm{Mn}+\mathrm{O}_{2} \rightarrow \mathrm{MnO}_{2} \\
& \mathrm{Mn}+2 / 3 \mathrm{O}_{2} 1 / 3 \rightarrow \mathrm{Mn}_{3} \mathrm{O}_{4} \\
& \mathrm{Mn}+3 / 4 \mathrm{O}_{2} / 2 \rightarrow \mathrm{Mn}_{2} \mathrm{O}_{3} \\
& \mathrm{MnO}+1 / 6 \mathrm{O}_{2} 1 / 3 \rightarrow \mathrm{Mn}_{3} \mathrm{O}_{4} \\
& \mathrm{Mn}+2 / 3 \mathrm{O}_{2} 1 / 3 \rightarrow \mathrm{Mn}_{3} \mathrm{O}_{4} \\
& \mathrm{Mn}_{3} \mathrm{O}_{4}+1 / 4 \mathrm{O}_{2} 3 / 2 \rightarrow \mathrm{Mn}_{2} \mathrm{O}_{3} \\
& \mathrm{Mn}_{2} \mathrm{O}_{3}+1 / 2 \mathrm{O}_{2} 2 \rightarrow \mathrm{MnO}_{2}
\end{aligned}
$$
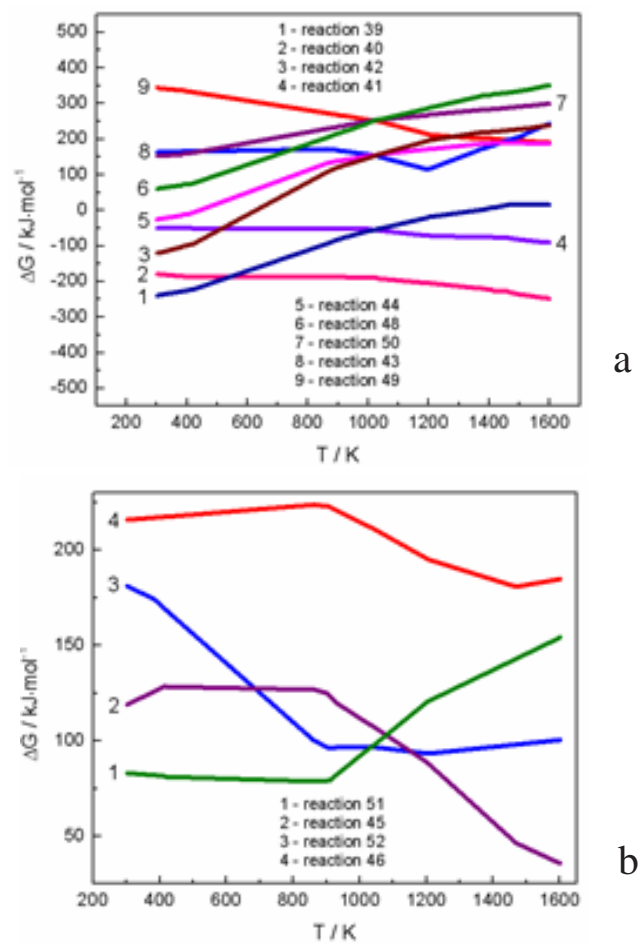

Fig. 5. The temperature dependences of $\Delta G_{T}$ for possible ways of oxidation of metallic manganese and manganese chlorides at interaction with titanium chlorides

From graphs at figure 6 it is visible that formation of all three oxides of manganese is thermodynamically favourable at all considered temperature range, but the further oxidation of oxides of manganese to the highest oxidation states is complicated. Values of Gibbs energy change are close to zero, i.e. the chemical equilibrium between $\mathrm{Mn}_{2} \mathrm{O}_{3}$ and $\mathrm{MnO}_{2}, \mathrm{Mn}_{3} \mathrm{O}_{4}$ and $\mathrm{Mn}_{2} \mathrm{O}_{3}$ is possible and oxidation $\mathrm{MnO}$ to $\mathrm{Mn}_{2} \mathrm{O}_{3}$ is thermodynamically not possible on all considered temperature range.

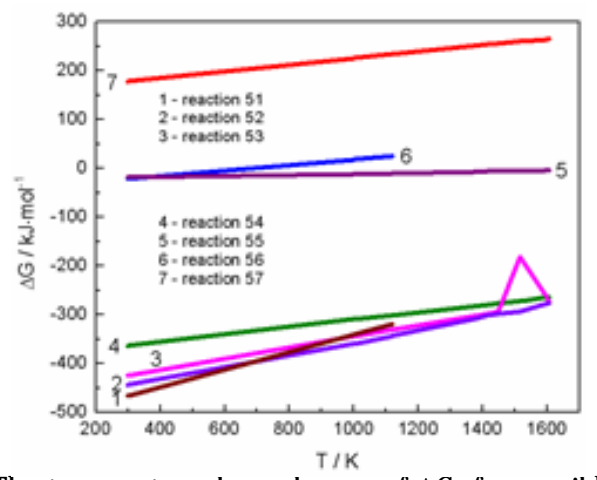

Fig. 6. The temperature dependences of $\Delta \mathrm{G}_{\mathrm{T}}$ tor possible ways of oxidation of metal manganese and its oxides under the influence of oxygen

\section{Conclusions}

On the basis of thermodynamical calculations it was defined that iron chloride is added to a titanium sponge due to interaction of Fe with titanium chlorides as a result of passing of reactions 1,4 and 6 .

On the other hand formation of oxides of iron is possible by any of the shown reactions at all considered temperature range.
Compounds of chromium can be formed at a temperature range above $1000 \mathrm{~K}$ and do not turn into a titanium sponge by thermal diffusion. Formation of chromium oxides is thermodynamically possible, but in practice they are not formed in significant quantities, because the oxide film on the surface of chromium prevents this process.

Compounds of nickel with chlorine can be formed at low temperatures. At higher temperature such process is impossible. The most part of nickel is introduced into titanium sponge through a formation stage of intermetallic compound $\mathrm{MgNi}_{2}$.

Formation of $\mathrm{MnCl}_{2}$ as well as manganese oxides is thermodynamically possible atall considered temperature range. However, in connection with low concentration of manganese in a steel $12 \mathrm{X} 18 \mathrm{H} 0 \mathrm{~T}$ (to $1 \%$ ) the introduction of some impurities of manganese in a titanium sponge does not affect the properties of the melted titan.

In conclusion iron and nickel and their compounds seem to be the basic impurities influencing mechanical characteristics of the melted titan. These impurities get to a titanium sponge due to interaction with titanium chloride reagent from which one can receive a titanium sponge.

Acknowledgements: This work was developed under the RomanianUkrainean collaboration under the coordination of the Romanian Academy in the framework of the research project, llie Murgulescu Institute of Physical Chemistry, nr.3-Electrode processes project, new electrical and corrosion system material, the theme nr.3.10-Ionic liquids: Properties and Electrochemical Applications. Authors equally contributed to this work. Authors wish to thank to Virgil Constantin who helped in graph editing and fruitful discussions.

\section{References}

1. SUZUKI, R.O., MATSUNAGA, T., ONO, K., HARADA, T.N., DEURA, T.N., Metallurgical and Materials Transactions B., 30, no.3, 1999, p.403. 2. SHAPOVAL, V.I., ZARUTSKY, I.V., MALYSHEV, V.V., Uskova, N.N., Chem. Rev., 68, 1999, p. 925.

3. MALYSHEV, V.V., GAB, A.I., BRUSKOVA, D.M., ASTRELIN, I., POPESCU, A.M., CONSTANTIN, V., Rev. Roum. Chem., 54, 2009, p.5.

4. Van VNUREN, J ournal of the Souther African Institute of Mining and Metallurgy, 109, no.8, 2009, p.455.

5. MALYSHEV, V.V., SHAKHNIN, D., Mater. Sci., 50, 2014, p. 80.

3. MALYSHEV, V.V., GAB, A.I., BRUSKOVA, D.M., ASTRELIN, I., POPESCU, A.M., CONSTANTIN, V., Rev. Roum. Chem., 54, 2009, p.5.

4. SHAPOVAL, V.I., ZARUTSKY, I.V., MALYSHEV, V.V., Uskova, N.N., Chem. Rev., 68, 1999, p. 925.

6. GARMATA, V.A., PETRUNKO, A.N., GALITSKIY, N.V., OLESOV, Yu.G., SANDLER R.A., Titan (Titanium). Metallurgiya, Moscow, 1983.

7. MALSHIN, V.M., ZAVADOVSKAYA, V.N., PAMPUSHKO, N.A., Titanium metallurgy, Metallurgy, Moscow, 1991.

8. SHAPOVAL, V.I., ZARUTSKY, I.V., MALYSHEV, V.V., Elektrokhimiya, 34, 1998, p. 1107. [in Russian]

9.GAMBOGI, J., GERDEMANN, S.J ., report DOE/ARC-1999-060, 2002.

10. TESLEVICH, S.M., TELIN, V.V., PETRUNKO, A.N., SHVARTSMARN, L.Ya., YATSENKO, A.P., Adv. Electrometallurgy, 2, 2004, p.45.

11. CERVONYI, I.F., IVASHCHENKO, V.I., LISTOPAD, D.A., Sci. Tech. J. Titan, 1, 2007, p. 20.

12. KIMURA, K., KATAYAMA, T., Nippon Steel \& Sumitomo Metal, Technical Report No.106, 2014.

13. CHERVONY], I.F., Listopad, D.O., SHAKHNIN, D., MALYSHEV, V.V., DONATH, C., NEACSU, E.I, CONSTANTIN, V., POPESCU, A.M., Rev. Chim. (Bucharest), 2019 (in press).

14. CHERVONYJ, I.F., LISTOPAD, D.O., Acta Mechanica Slovaca, 13, 2009, p.40.

15. KUBASHEVSKY, O., OLKOKK, S.B., Metallurgical thermochemistry. M., Metallurgy, Moscow, 1982.

16. TESLJ UK, M.J., Metal compainds with structure of phases of laves. İ., Science, Moscow, 1969.

\section{Manuscript received: 28.06 .2018}

